\title{
Working after age 50 in Spain. Is the trend towards early retirement reversing?
}

\section{Madelin Gómez-León and Pau Miret-Gamundi*}

\begin{abstract}
As the baby boom cohort approaches retirement, there has been considerable uncertainty about the economic sustainability of the social security systems in most of the developed world. In recent decades, Spain has had both one of the oldest populations and the lowest levels of employment among the population aged 50 and over in Europe. This article addresses these issues by investigating the relationship between ageing and labour participation in the adult population. We examine the changes in employment exit patterns among men and women between 1999 and 2012, and the factors which influence early retirement, using the Spanish Labour Force Survey (panel dataset). We found clear gender effects in retirement behaviour in terms of the shares of the population who were not working and the predictors of early retirement. The partner is shown to be more relevant in the retirement timing decisions of men, while dependents are found to be more relevant in the decisions of women. Moreover, the likelihood of exiting the labour market early appears to be decreasing among women, and increasing among men.
\end{abstract}

\section{Introduction}

Since the end of the $20^{\text {th }}$ century, scholars and policy-makers in general have been increasingly concerned about the demographic, social, and economic consequences of population ageing (Dixon 2003; Christensen et al. 2009; Bloom et al. 2011). In discussions of this issue, much attention has been focused on the relationship between demographic ageing and the labour market. The declining workforce is driven by two factors: on the one hand, the working-age population is decreasing

\footnotetext{
* Madelin Gómez-León (corresponding author), ESRC Centre for Population Change, Building 58, Room 2033, Faculty of Social and Human Science, University of Southampton, SO17 1BJ, UK Email: M.Gomez-Leon@southampton.ac.uk

Pau Miret-Gamundi, Senior Researcher, Centre for Demographic Studies, Autonomous University of Barcelona, Spain
} 
due to sustained low levels of fertility (Barwell 2001; Aaronson et al. 2006); while on the other, the retired population is increasing, especially with the baby boom cohorts approaching retirement ages (Díez 1999, Auer and Fortuny 2000, Díaz and Llorente 2005). This phenomenon of a decline in the size of the population of active ages has led some observers to express considerable uncertainty about the economic sustainability of the European welfare system, and particularly of Europe's pension systems.

Several studies have focused on the transition from working to non-working status at older adult ages. Job characteristics, labour market structures, and the institutional background play significant roles in the transition from employment to permanent retirement (Burtless and Moffitt 1984; Antolín and Scarpetta 1998; Cano et al. 2000; Flippen and Tienda 2000). Furthermore, a range of demographic characteristics - such as gender, age, educational attainment, and family responsibilities - have considerable influence on the timing of retirement (Auer and Fortuny 2000; Garrido 2004; Ortiz 2004; Flores 2008; Dittrich et al. 2011).

The Spanish population structure is among the oldest in Europe (Puyol 2005). Moreover, as in most other European countries, in Spain the ages at which adults leave the labour market have been falling (Quinn 1999; Gendell 2001; Garrido and Chuliá 2005; Christensen et al. 2009).

This paper examines the patterns of employment of the adult population in Spain, paying special attention to the permanent early exits of older adults and the interrelationship between an individual's early retirement and his or her family arrangements. Among adults approaching the state pension age (SPA), ${ }^{1}$ we seek to characterise the nature of labour market exits which result in permanent inactivity, evaluating the effects of socio-demographic determinants on withdrawal from employment. Specifically, this paper will:

1. Describe the employment patterns of individuals near the SPA in Spain, before and after the economic crisis in 2008.

2. Examine the socio-demographic determinants which influence the transition to permanent labour inactivity among older adults in Spain.

The focus of the paper is on early exits from the labour market among the adult population; i.e. entry into retirement by individuals who have not yet reached the SPA (age 65), when they can claim $100 \%$ of work-related pension benefits. Before this age, access to various benefit regimes is based on contextual conditions, individual characteristics, and the terms of pension schemes. These regimes will be described in greater detail in the following section.

1 The state pension age (SPA) was 65 for both sexes in Spain until 2013, when it started to gradually increase. The SPA will reach 67 in 2030. The SPA is the age at which an individual can apply for $100 \%$ of a retirement pension, based on the number of years worked and the contributions made to the pension system. 
We will study exits from employment among adults between the ages of 50 and 64, or under the SPA (the point at which the majority of workers enter retirement). We have chosen to focus on this age range in our study because previous research has shown that labour market participation rates of males start to decline around age 50 (Gómez-León 2013). Moreover, this decline appears to be driven by the difficulties individuals face in re-entering employment at this stage of their life (Chan and Stevens 2001; Hofäcker 2006), and the incentives they are offered by companies or by private or public schemes to remain outside of the workforce (Shultz et al. 1998; Oswald 1999; Dittrich et al. 2011).

The transition to inactivity among the adult population can be analysed from a variety of perspectives and with a multiplicity of determinant factors. Using a demographic approach, we will investigate in this paper the changes in the ages at which workers exit employment and the socio-demographic factors which influence early retirement among the adult population, including differences in sex, educational attainment, and household composition. Specifically, we will analyse the evolution of employment and early exits among the adult population in Spain, highlighting the effects of family and economic contexts during the period of study (1999-2012) and the gender differences in the Spanish labour market.

\section{Contextual and individual background}

In recent years, European governments have expressed concerns about the decline in the size of the working population, whose contributions are needed to sustain the dependent population; i.e. those who are not in employment. Recent policy debates have therefore focused on ways to encourage people to spend more time in employment, and in particular to delay their permanent exit from the labour market. Regulations which limit early retirement and which extend the retirement age beyond the SPA have been introduced in most European countries (European Union 2012). Yet despite these efforts, in recent decades the employment rates of 55-64-year-olds have declined considerably in most European countries, and the mean actual retirement age has fallen in most OECD countries (Auer and Fortuny 2000; López 2004; Antón et al. 2007; Bloom et al. 2011). In the case of Spain, where the SPA was set at 65 until 2013, the mean age of exit has consistently been below this level for the last three decades, with a mean age of exit of around 62 in 2012.

Withdrawal from the labour market is basically determined by three interrelated dimensions: the institutional or legal context (macro level), the structural or economic context (meso level), and individual characteristics (micro level).

The first dimension is the institutional or legal context, which is determined primarily by the policy and legal framework. This context limits and conditions the duration of an individual's years in employment by regulating the age of entrance into the labour market and the age of exit or retirement. The retirement age is typically set through regulated sources of income, such as social pensions or other economic benefits (Casey and Wood 1994; García 2003). Individuals who 
have worked for a period of time generally have access to a retirement pension after fulfilling certain requirements. If individuals are leaving the labour market temporarily or have not yet met the requirements for retirement, they can apply for other types of benefits, including unemployment benefits; this is a widely used pathway to an early labour market exit among older adults, as discussed below.

The decline in the mean age of retirement is attributable in large part to the introduction in the 1970s and 1980s of specific schemes and regulations which facilitated early retirement. The explicit goal of these schemes, which were promoted by governments and companies, was to reduce the size of the labour force (Shultz et al. 1998; García 2003). However, in countries such as Finland and the UK, policies with the opposite aim have been promoted since the end of the 1990s, with positive but limited results (Nickell 2003; López 2004; Díaz and Llorente 2005; Garrido and Chuliá 2005).

The universal Spanish social security system dates from 1963 (Erdogan-Ciftci et al. 2008), when a unitary model of social protection encompassing both private and sector-based schemes was implemented. In addition to providing retirement and unemployment benefits, this social protection system provides other forms of support, including benefits for widows and for individuals with work-related disabilities. $^{2}$ The pension system is financed through a pay-as-you-go model. A range of schemes was created within this system to allow for early retirement. For example, individuals may apply from the age of 50 onwards to receive various kinds of social benefits which can later be linked to early retirement benefits (see Table 1).

The second dimension corresponds to the structural or economic context, and thus refers to the labour market conditions which can affect workforce supply and demand. For example, lower employment rates may be caused by an economic recession or by changes in the economic system. Several studies have found that labour inactivity among elderly adults tends to be especially high in countries in which early retirement programmes have been heavily promoted (Blöndal and Scarpetta 1998; Gruber and Wise 1999). In many cases, these programmes had been introduced as a response to an economic recession, but went on to become permanent mechanisms of labour force regulation.

By the end of the $20^{\text {th }}$ and the beginning of the $21^{\text {st }}$ centuries, the Spanish economy was growing steadily. This process of expansion was based on a largescale restructuring of industry and the economy during the 1980s, and on Spain's integration into the European Union. Largely as a result of participation in early retirement schemes, the Spanish labour force supply was reduced in almost all of the productive sectors during this period, and especially in the industrial and agricultural sectors. At that time, agriculture was the most important sector of the

2 Detailed information on the benefits and the pension system in Spain can be found in: Cano et al. (2000). 'El mercado de trabajo y su medición en España.' Estadística Española Vol. 42 (Núm. 146), Zubiri (2003). El futuro del sistema de pensiones en España. Madrid, Instituto de Estudios Fiscales. 
Table 1:

Features of pathways to early exit from employment in Spain

\begin{tabular}{lll}
\hline Age & $\begin{array}{l}\text { Access to (early) exits schemes or } \\
\text { social benefits }\end{array}$ & $\begin{array}{l}\text { Years in employment } \\
\text { required (min-max) }\end{array}$ \\
\hline 50 & $\begin{array}{l}\text { Social benefits (i.e. unemployment up to 2 years) } \\
\text { Early retirement for workers in specific } \\
\text { dangerous occupations }\end{array}$ & 15 \\
52 & Early retirement for disabled workers & 15 \\
$52-56$ & Early retirement schemes for particular workers & $15-30$ \\
60 & Compulsory early retirement & 30 \\
60 & & $33(2013)$ \\
$61(2013)$ & Partial retirement (voluntary) & 30 \\
61 & & $33(2013)$ \\
$63(2013)$ & Full retirement & $10-25$ \\
65 & & $15-35(1980)$ \\
& & $15-38,5(2013)$ \\
$65-67$ (2013) & Part work/Part retirement & \\
65 & & \\
$65-67$ (2013) & Delayed retirement & \\
After 65-67 (2013) & &
\end{tabular}

Source: Ministerio de Empleo y Seguridad Social (http://www.empleo.gob.es) and Sindicato de Comisiones Obreras (http://www.ccoo.es).

Spanish economy (Díez 1999). Although male labour participation continued to decline, with exits occurring as early as at age 50, employment rates among the $50-54$ age group generally rose during the period of steady economic growth which started at the end of the 1990s. (Miret-Gamundi and Gómez-León 2009).

The third dimension refers to the individual context, which influences both entry into and duration of participation in the labour market. During the last century, key life events such as family formation, educational achievement, and entry into the labour market underwent important transformations, both in terms of the moment at which these events occur, as well as in the length of time spent in various states throughout the life cycle (Baizán et al. 2001; Esping-Andersen 2004; Olmo and Herce 2011). The delaying of these events, together with rising life expectancy, may lead us to assume that events such as the exit from employment should also be delayed. However, improvements in health and life expectancy have not translated into a longer working life. Instead, the proportion of the population who leave the labour market in their early fifties has been increasing over time. This represents a premature exit period of nearly 15 years prior to the defined SPA (age of 65). We focus on in our analysis this age range.

Together with macro-economic determinants, individual determinants heavily influence the exit from the labour force. Patterns of employment and of the transition 
to retirement differ significantly by gender, especially at the ages in which we are interested: i.e. 50-64. In Spain, men have much higher rates of employment than women, as men are generally expected to assume the breadwinner role, while women tend to be engaged in informal work, such as taking care of the household and the family (Garrido 2004; Lindeboom and Kerkhofs 2009). Moreover, the low activity rates among women appear to be related with their living arrangements, as women who live with a partner are much less likely to be working (Even and MacPherson 1994; Ruhm 1996; Ortiz 2004).

The likelihood of remaining in the labour force also differs by type of occupation. In this paper, educational attainment will be used as a proxy for occupation, as previous studies have shown that people with higher levels of education are more likely than their less educated counterparts to remain in the labour market (Sicherman and Galor 1990; Garrido and Chuliá 2005; Dittrich et al. 2011).

While in our analysis we include several determinants of the decision to retire, such as age, education, family arrangements, and the employment status of the partner; other factors which are not included here may also play an important role, and should therefore be mentioned. For instance, a large number of studies have shown that health status is a predictor of the transition to retirement (Pinzón-Fonseca 2011; García-Gómez et al. 2014). Moreover, the employment history and income of an individual (with women having shorter durations and lower wages in general) may also determine earlier or later transitions to retirement.

\section{Data and methods}

\subsection{Data and variables}

The data used in this study come from the Spanish Labour Force Survey (LFS), conducted by the National Institute of Statistics in Spain. The LFS is a nationally representative rotating panel, set as a continuous quarterly survey (one-sixth of the sample is changed in each round). As a result, each household could be followed in up to six waves, for a total of a year and a half. The survey collects information (the reference is the week previous to the day of interview) regarding all of the members of the household, ${ }^{3}$ including information on the respondents' sex, marital status, educational attainment, and labour activity.

The study used all of the waves of the LFS data from 1999 to 2012, or 161 waves for the entire period. This allowed us to analyse short-term changes, and to conduct a more general analysis of the labour market (Greene 2004). Our analysis starts in 1999, since this is the year in which the relationship of the individuals within the household can pinpointed; in particular, we are interested in the presence of children,

3 Secondary or stage households are excluded, as are collective households, hospitals, and military lodgings. 
Table 2:

Summary statistics of the sample

\begin{tabular}{|c|c|}
\hline Variables & $\begin{array}{l}\text { Frequency of total observations / } \\
\text { Mean (standard deviation) }\end{array}$ \\
\hline \multicolumn{2}{|l|}{ Dependent variable } \\
\hline \multicolumn{2}{|l|}{ Employment status } \\
\hline Working & $49.5 \%$ \\
\hline Not working & $50.5 \%$ \\
\hline \multicolumn{2}{|l|}{ Main independent variables } \\
\hline \multicolumn{2}{|l|}{ Household arrangements } \\
\hline Living alone & $6.4 \%$ \\
\hline Living with partner only & $21.4 \%$ \\
\hline Living with partner and dependent children & $9.6 \%$ \\
\hline Living with partner and parents & $2.7 \%$ \\
\hline Living with dependents (children/parents) & $5.2 \%$ \\
\hline Living with partner/older children/others & $54.7 \%$ \\
\hline \multicolumn{2}{|l|}{ Partner's employment status $(n=442,132)$} \\
\hline Partner is working & $54.8 \%$ \\
\hline Partner not working & $45.2 \%$ \\
\hline \multicolumn{2}{|l|}{ Covariates } \\
\hline Sex Males & $40.3 \%$ \\
\hline Females & $59.7 \%$ \\
\hline Age & $56.6(4.46)$ \\
\hline $50-54$ & $36.6 \%$ \\
\hline $55-59$ & $33.3 \%$ \\
\hline $60-64$ & $30.0 \%$ \\
\hline \multicolumn{2}{|l|}{ Education level } \\
\hline Illiterate & $2.4 \%$ \\
\hline No schooling & $11.6 \%$ \\
\hline Primary & $38.6 \%$ \\
\hline Vocational training & $19.9 \%$ \\
\hline Secondary & $15.5 \%$ \\
\hline Bachelor's or higher & $12.1 \%$ \\
\hline Observations (individuals-waves) & $1,750,410$ \\
\hline Individuals & 533,145 \\
\hline
\end{tabular}

Source: Spanish Labour Force Survey.

parents, and partners. Our study population is comprised of all of the respondents aged 50 to 64 who could have been observed up to six times during the period of analysis. We thus have 1,750,410 observations of a final subsample of 533,145 individuals, $59.7 \%$ of whom are females. Descriptive statistics of the variables used in the analysis are presented in Table 2. 


\section{Dependent variable}

A variety of approaches can be applied to analysing early retirement behaviours. Defining the group of people who take early retirement is challenging. If we take into account all of the individuals who are not working, the group could include all of the following: those who have never worked, those who have stopped working but do not meet the requirements to receive an early or a full retirement pension, those who are receiving a pension, and those who combine part-time employment with pension benefits. In our study, we follow previous scholars who differentiated between individuals who are actively engaged in employment and those who are not (Antolín and Scarpetta 1998; Antón et al. 2007). Therefore, we will focus on two main states: 1) working and 2) not working. This approach allows us to include in the non-working group all individuals who were not actively engaged in employment, regardless of whether they were receiving a retirement or disability pension or another form of social benefits, or had no income at all.

\section{Independent variables}

Our study focuses on the differential effects of family arrangements for men and women. Based on a literature review, we also include other factors as control variables. Table 2 shows the main characteristics of the variables used in the analysis. Thus, the age of individuals is split into three different groups to control for the increasing likelihood that they will retire as they approach the age of 65 .

Economic factors are controlled for with the variable time. During the period of study, a phase of substantial economic growth was observed (accompanied by an increase in labour force demand) until 2008, when the economic crisis hit the Spanish economy. A reversal of this positive trend then occurred (at least in terms of demand for labour among males, an issue we will analyse in the following section) and employment rates at all ages were negatively affected. To account for these changes, time will be split into dummy variables for each year in the study (19992012).

According to the human capital theory developed by (Becker 1964), individuals who complete higher levels of education are expected to have higher wages. Moreover, other studies (Sicherman and Galor 1990) have pointed out that the acquisition of education, knowledge, and experience is associated with improvements in working conditions and status over time. Thus, education increases an individual's chances of entering and remaining in employment, and of getting a better job (Garrido and Chuliá 2005; Dittrich et al. 2011). However, in a study which compared Germany with the United Kingdom (Oswald 1999), a significant association between higher education levels and the postponement of the exit from employment was found among German men only.

Because the Spanish educational system has undergone five major reforms in recent decades, the education variable recorded in the LFS has changed over time. Therefore, the standardisation of the variable (see Appendix A.1) takes into account 
the changes in the classifications used. The categories for the education variable are as follows:

1. Illiterate or non-schooled

2. Primary

3. Secondary

4. Vocational training

5. Bachelor's or higher

In terms of household characteristics, from 1999 onwards the LFS dataset includes the relationships of all of the household members surveyed. This information allows us to derive a variable which reflects the respondents' family arrangements, including their relationships to their parents, their partner, and their children. We also take into account the age of the household members, assuming that the household members who were under age of 16 were dependents, and that the presence of dependents would be associated with a decreased probability of being in employment among women, and an increased probability among men. In addition, we assume that adults who were living with a parent were more likely to change jobs or exit employment, as the elderly parent was likely to be a dependent (Schneider et al. 2013).

We also examined gender differences in the influence of the employment pattern of the partner/spouse on the probability of being out of the labour market. Since the retirement decision is often made jointly by the couple (Ruhm 1996; Mark et al. 1999; Ortiz 2004), using the partner's employment status variable, we expect to observe among those respondents whose partner was in employment a reduced risk of being out of work.

Regarding household arrangements, the variable of living arrangement has being created with the following mutually exclusive categories:

- Living alone

- Living with a partner only

- Living with a partner and dependent children

- Living with a partner and parents

- Living with potential dependents (young children or parents)

- Living with a partner/adult children/others

\subsection{Methods (data analysis)}

As the study focuses on the early retirement patterns of the adult population in Spain, we start the first section with a general descriptive analysis which compares the age of exit from employment for different European countries, and examines the remaining life expectancy at age 60 in Spain according to the years in employment from this age onwards. 
The employment patterns are then built using the LFS in order to illustrate the trends associated with different activity statuses (employed/unemployed/inactive) for males and females aged 50 to 64 between 1976 and 2012.

To ensure that our estimates are unbiased-i.e. are not affected by unobserved individual characteristics - the relationship between family arrangements and the permanent exit from employment was estimated using a random effects (RE) model. RE models are useful in this context because they allow us to take into account the fact that each individual can have more than one observation over time (Diggle 2002); and up to six observations in our case. The model assumes that the variation across individuals is random and is uncorrelated with the other predictors included in the model. An advantage of the RE model is that it allows us to include in our analysis time-invariant variables, such as education and sex, and to specify those characteristics which may or may not influence the predictor covariates. To check for the precision of the results and the inclusion of the time-variant covariates, the results from the RE model were compared with the ordinary least square (OLS) models.

As our dependent variable is dichotomous, logistic regression with random effects was used to estimate the probability of being out of the labour market, including other variables to control for time, age, economic activity of the partner, and education.

While our control variables cover a range of important determinants, the lack of other factors could bias our results, and should thus be mentioned. For instance, our dataset does not include information about health status, which is an important predictor of the transition to retirement. Moreover, the employment history and income of the individuals (with females having shorter employment careers and lower wages in general) may also determine earlier or later transitions to retirement.

\section{Demographic potential of the workforce}

The current political and social debates regarding labour force participation often focus on ways to encourage people to work beyond the SPA (age 65). However, a large proportion of individuals do not remain active in the labour market up to this age, as the mean age of exit from the labour market indicates.

Figure 1 shows that several European countries have a mean age of exit below the SPA, albeit with important differences by gender. Moreover, in some countries the situation does not appear to have improved between 2010 and 2012. Across the European Union (UE-27), the mean age of exit in 2012 was 63 for females and 64 for males, up from 61 for both genders in 2010. Three main patterns can be distinguished from the figure. In the first group of countries, which includes Sweden, Denmark, and Switzerland, the mean age of exit is relatively high, and even surpasses the SPA for males. In the second group of countries, which includes Germany and Spain, the mean age of exit is higher for females than for males, with Spain showing modest improvements between the 2010 and 2012. In the third group 


\section{Figure 1:}

Average effective age of labour market exit and state pension age (SPA) by sex. European Union and selected countries (2010 and 2012)

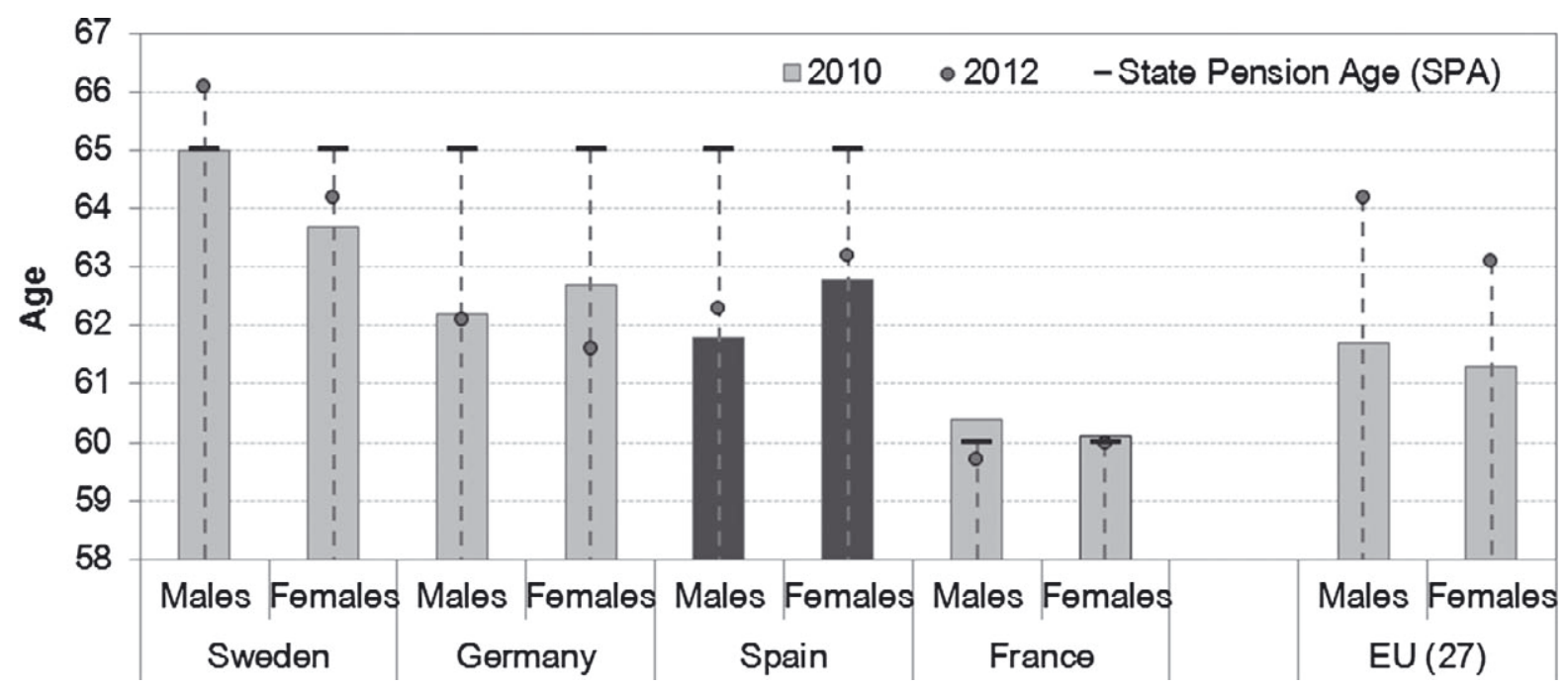

Source: Eurostat, data for 2010 consulted on 24/06/2013; 2012 consulted on 27/11/2014 (OECD 2013).

of countries, which includes France and Italy (with differences by sex), the SPA levels are very low compared with the other countries. These countries are, however, in the process of raising the age beyond 65, in line with the rest of the European Union.

This pattern of increasingly early exit from employment has been occurring since the 1970s and 1980s, when most of the OECD countries used early retirement programmes to respond to economic crises and restructuring. Since the 1980s in Spain, the total number of years spent in employment has been falling due to early retirement. Meanwhile, over the same period, life expectancy has been rising.

These two opposing phenomena are depicted in Figure 2, which shows the life expectancy at birth (light grey bars) and the years spent in employment (dark grey bars) according to the age of exit from the labour market. As we can see from the graph, in 2010 life expectancy at birth was 79.1 for men and 85.1 years for women, 2.1 and 4.9 years longer than in 1970. However, during the same period, the number of years spent in employment decreased, as people were leaving the labour market at progressively young ages.

It is noteworthy that in 1970 the average age of exit from employment was considerably higher than 65, especially among working women, who, on average, remained in the labour market beyond age 70. By 1990, a significant reduction in the number of years the average person was working had already taken place, with a large share of the labour force retiring before age 65. This trend was especially pronounced among males. By 2010, the number of working years had fallen ever further, to 3.2 years below 65 for men, and to 2.2 years below 65 for women. 
Figure 2:

Life expectancy at birth by employment status and sex. Spain $(1970,1990$, and 2010)
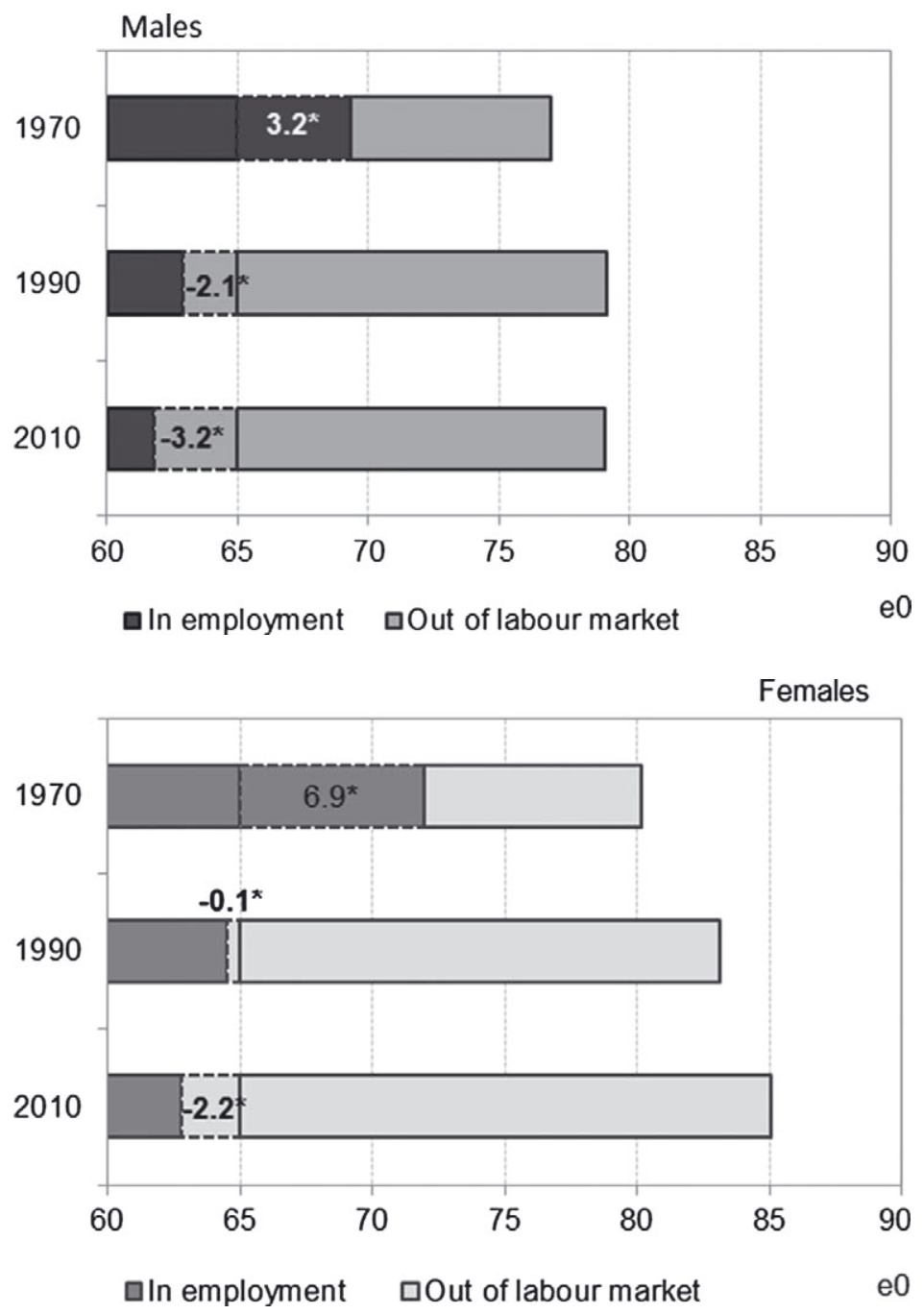

Note: Years in employment are calculated using the mean age of labour market exit.

$\left(^{*}\right)$ The value indicates the difference between the mean age of labour market exit and the SPA (at age 65).

Source: Institute of National Statistics (www.ine.es) for the life expectancy; Eurostat (http://epp.eurostat.ec. europa.eu) consulted on 24/06/2013 for the mean age of exit from employment.

Figure 2 also shows that the effective mean age of retirement-and, hence, the average number of years an individual spends in the labour market-has decreased over the last 40 years. This has occurred despite political efforts to increase the mean age of retirement to 67; a policy which has already been implemented in countries such as Spain and Germany. 


\section{Labour market patterns of the adult population in Spain}

Having documented the decrease in the mean age of labour market exit, we now examine the labour market status of individuals who are under age 65. Figure 3 shows the proportions of Spanish males aged 50 to 64 who were employed, unemployed, or inactive for the period 1976-2012. The highest level of employment was observed at the beginning of the period, or in the mid-1970s, when around $80 \%$ were working. This level had dropped markedly by the end of the 1970s and the beginning of the 1980s, stabilising in 1985 at $65 \%$; but then falling even lower during the 1990-1994 economic crisis, to 58\%. During the 1995-2008 period of strong economic growth, employment levels increased, but only to $69 \%$; far lower than the levels reached in the 1970s. The economic crisis of 2008 disrupted this trend, with employment falling to 1996 levels, or to about 60\%.

Given the decline in employment levels in the first half of the period, the unemployment rate should have risen more steeply than it did: among 50-64-yearolds, the unemployment rate increased only from 2\% in 1976 to $8 \%$ in 1996 and to $12 \%$ by 2012 . It therefore appears that a very large number of people in this age group who were not employed had become inactive, thus permanently exited the labour market shortly thereafter.

The proportion of 50-64-year-old men who were inactive was around $15 \%$ in 1976. This share had doubled by 1994, and then remained at around 25\% until 2012. Even during times of economic growth, the share of 50-64-year-old men who were inactive remained steady. This trend is likely attributable to the intensive use of the early retirement programmes which were created during the Spanish restructuring process of the 1980s, and which continued to be available in the subsequent decades.

Figure 4 shows the labour market trends among 50-64-year-old women from 1976-2012. When we compare these trends with those shown in Figure 3, we can see that much higher proportions of women were out of the labour market for the entire period of analysis. From 1976 to 1994 , between $75 \%$ and $77 \%$ of women aged 50-64 were inactive. These percentages decreased steadily to $47 \%$ by 2012 . This trend illustrates the changes in Spanish society since the 1980s, with women entering most spheres of socio-economic and political life. However, for the adult population nearing retirement, this shift did not take place until the mid-1990s.

Unlike male labour market participation, female labour market participation does not seem to have been affected by the economic crisis in the 1970s or the 1990s. However, the economic crisis which started in 2008 appears to have had a modest impact on female labour participation, albeit with a certain delay. For instance, the percentage of women in employment stagnated in 2009-2010, and had fallen slightly by 2012 . This decline has affected the unemployment rates of women. In the first part of the period of analysis, unemployment rates for women were very low, which indicates that relatively few women of these ages were actively looking for a job. This situation started to change in the 1990s, but the female unemployment rate remained low, at around 5\%. 
Figure 3:

Male population aged 50-64, by labour market status. Spain (1976-2012)

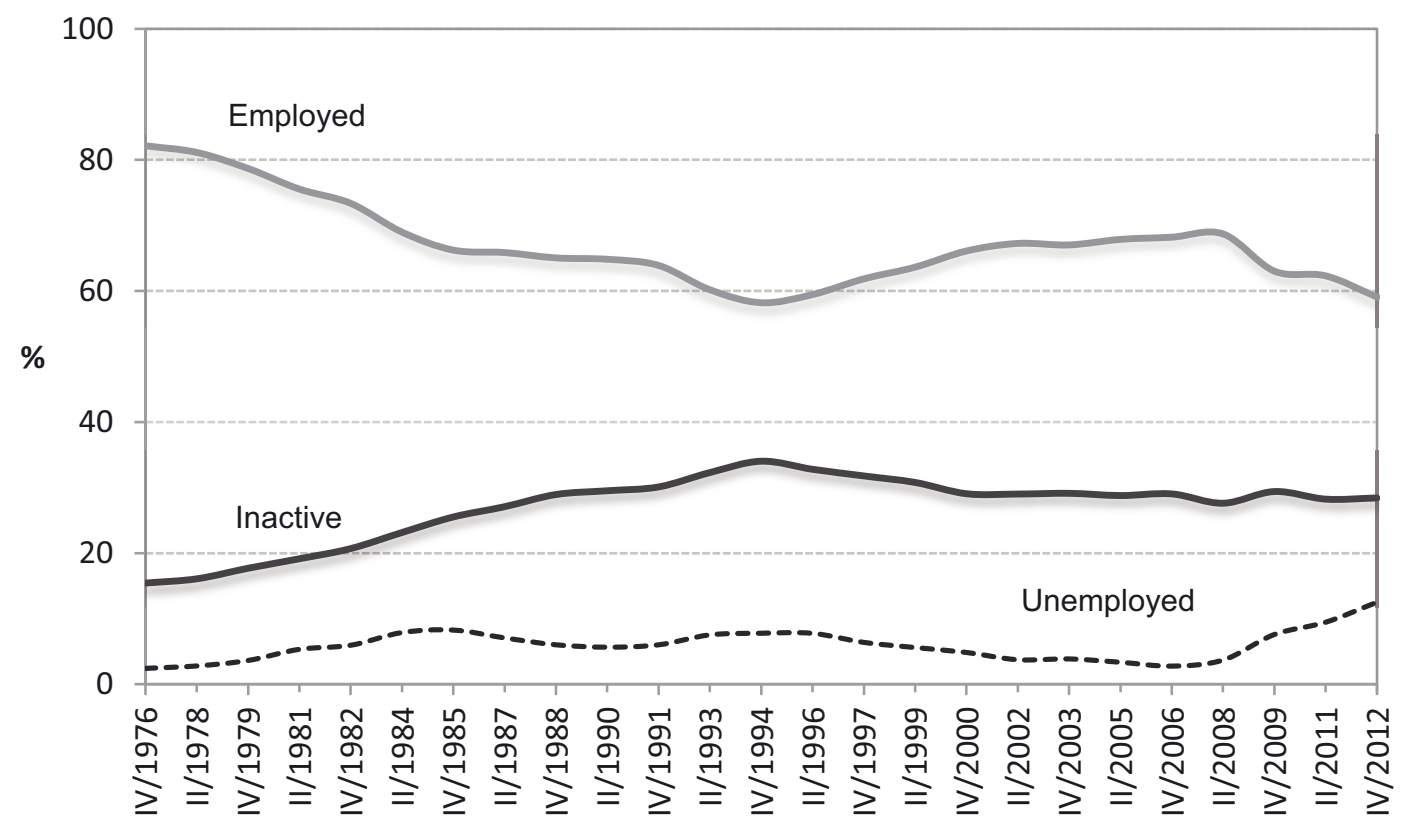

Note: Roman numbers correspond to the trimester in any given year.

Source: Spanish Labour Force Survey (LFS).

Especially remarkable is the significant increase in the unemployment rate for women aged 50-64 since the start of the crisis in 2008, to $10 \%$. This trend is particularly interesting, as until recently this was one of the population groups who seem to have been most protected from the crisis, as older women are especially likely to be employed in the public sector with a permanent contract. This higher rate, may, however also be a response to the higher unemployment and inactivity rates among men in this on-going crisis.

During the entire period of study (1976-2012), there were clear sex differences in labour market participation: i.e. the male trends followed the ups and downs of the economic cycles, whereas the female trends did not. In the next section we will analyse sex-specific employment trends for different periods of time and different levels of educational attainment.

\section{Demographic determinants of early retirements}

The previous sections showed that male and female patterns of employment clearly differed. While the participation levels of women were much lower than those of men throughout the period, the increase in labour market participation among women does not appear to have been affected by the economic downturn which started in 2008. Moreover, this pattern of a low level of employment among women 


\section{Figure 4:}

Female population aged 50-64, by labour market status. Spain (1976-2012)

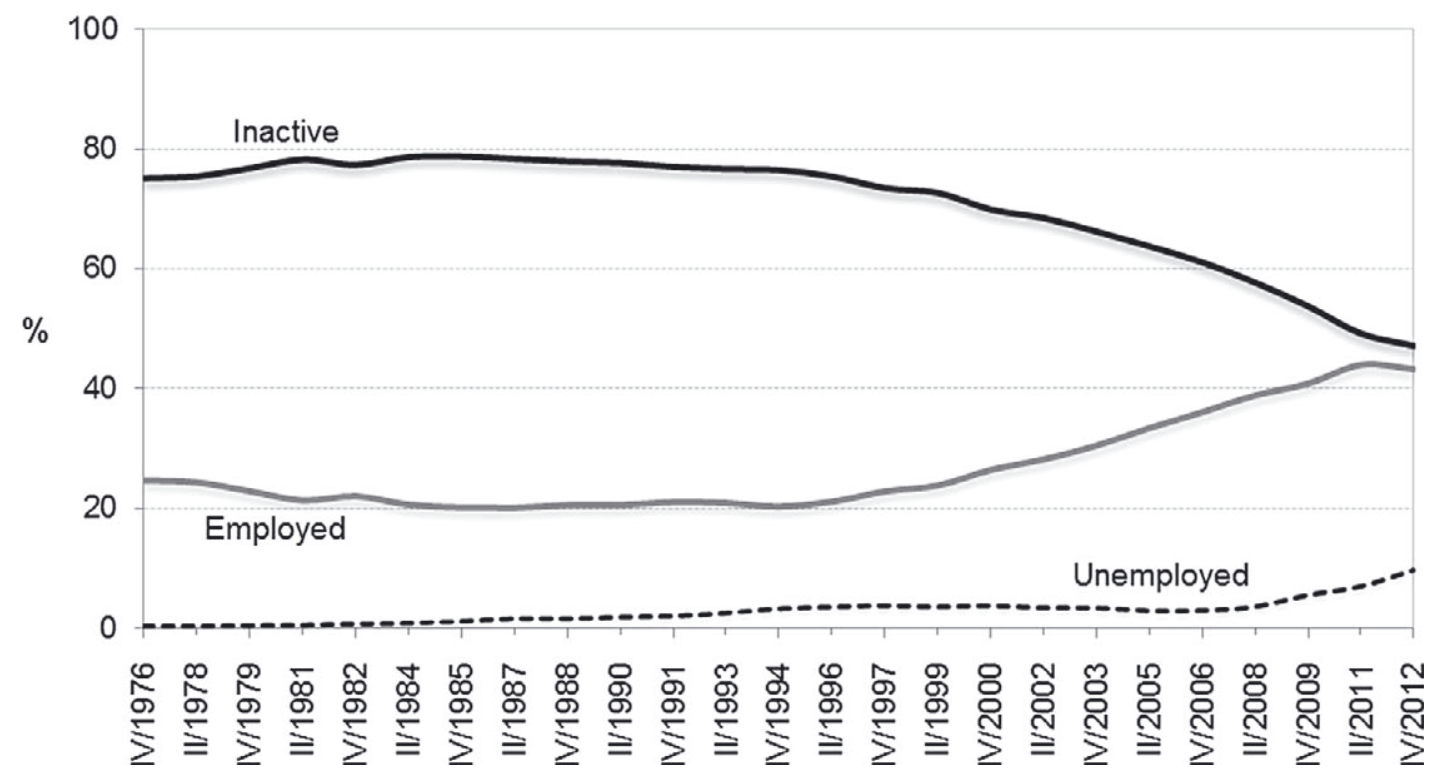

Note: Roman numbers correspond to the trimester in any given year.

Source: Spanish Labour Force Survey (LFS).

at older ages could be also be related to the fact that many women take on the role of family caregiver, especially if there is another source of income in the household (which could be the partner's income or the pension benefits of the parents).

In the following analysis, we will address this issue by selecting two models (one for each sex) to test the effect of having potentially dependent family members at home; and the effect of time to control for changes in the patterns before and after the 2008 crisis (using the period between 1999-2008).

Before discussing in detail the results of the analysis for males and females, we first present the results of two models which we ran for the entire sample (males and females together) to check whether it was pertinent to use the random effects model instead of the simple logistic regression (see Appendix A.2). The results show the same effect (negative or positive) for all of the variables in the study; however, the levels are significantly different, with higher coefficients for the random effects model. Moreover, although the variance is in large part due to the differences across the waves $(96.8 \%)$, the residuals within individuals are highly significant $\left(4.6^{* * *}\right)$; it is therefore important to take this variance into account.

Having analysed in the previous section employment status in the cross-sectional data for the entire period, we will now focus on 1999-2008, a period for which we have data on the respondents' family arrangements. Using discrete panel data, Table 3 depicts for this period the transition probabilities of changes in employment states over two consecutives waves (up to six waves for each individual), for males and females separately. As we noted in the literature review, entry into employment 
Table 3:

Transitions in employment status between waves by sex, period 1999-2012. Spain (50-64 years old)

\begin{tabular}{|c|c|c|c|c|c|c|c|c|c|}
\hline & \multirow[b]{2}{*}{ Males } & \multicolumn{3}{|c|}{ State in $t_{x+1}$} & & \multirow[b]{2}{*}{ Females } & \multicolumn{3}{|c|}{ State in $t_{x+1}$} \\
\hline & & Working & $\begin{array}{r}\text { Not } \\
\text { working }\end{array}$ & Total & & & Working & $\begin{array}{r}\text { Not } \\
\text { working }\end{array}$ & Total \\
\hline \multirow[t]{3}{*}{$\begin{array}{l}\text { State } \\
\text { in } t_{x}\end{array}$} & Working & $\begin{array}{r}402,830 \\
050 \%\end{array}$ & $\begin{array}{r}17,146 \\
41 \%\end{array}$ & 419,976 & \multirow{2}{*}{$\begin{array}{l}\text { State } \\
\text { in } t_{x}\end{array}$} & Working & $\begin{array}{r}219,168 \\
936 \%\end{array}$ & $\begin{array}{r}14,948 \\
64 \%\end{array}$ & 234,116 \\
\hline & $\begin{array}{l}\text { Not } \\
\text { working }\end{array}$ & $\begin{array}{r}10,750 \\
5.1 \%\end{array}$ & $\begin{array}{r}199,614 \\
94.9 \%\end{array}$ & $\begin{array}{r}210,364 \\
100.0 \%\end{array}$ & & $\begin{array}{l}\text { Not } \\
\text { working }\end{array}$ & $\begin{array}{r}12,840 \\
3.6 \%\end{array}$ & $\begin{array}{r}339,969 \\
96.4 \%\end{array}$ & $\begin{array}{r}352,809 \\
100.0 \%\end{array}$ \\
\hline & Total & $\begin{array}{r}413,580 \\
65.6 \%\end{array}$ & $\begin{array}{r}216,760 \\
34.4 \%\end{array}$ & $\begin{array}{r}630,340 \\
100.0 \%\end{array}$ & & Total & $\begin{array}{r}232,008 \\
39.5 \%\end{array}$ & $\begin{array}{r}354,917 \\
60.5 \%\end{array}$ & $\begin{array}{r}586,925 \\
100.0 \%\end{array}$ \\
\hline
\end{tabular}

Note: The transition probabilities use panel data for nested observations within individuals.

Source: Spanish Labour Force Survey (LFS).

at adult ages is relatively rare. As expected, we observed relatively few transitions into or out of the labour market in our sample of individuals aged 50 to 64, although the patterns differed by sex.

In Table 3, we have 630,340 observations of males and 586,925 observations of females which could have been recorded across the six waves. In the last observation, $65.6 \%$ of the men were working. Meanwhile, more than half $(60.5 \%)$ of the women were not working - a higher share than the one observed in the crosssectional analysis, specially after 2008.

This stresses the importance of taking into account the differences in the behavioural patterns of men and women. Relatively few women were still working at these ages, but among those who were working, their probability of remaining in employment was similar to that of men. Thus, employment status was highly stable among both sexes, with more than $90 \%$ staying either in or out of employment. By contrast, the rate of transition into employment was lower with 5\% among men and nearly $4 \%$ among women.

The results from the logistic model with random effects are presented in Table 4. The models show a high degree of intraclass correlation between the residuals within individuals and between the overall error terms for females and males (96\% and $97 \%$, respectively). Meanwhile, the standard deviation within groups should also be taken into account (8.6 and 9.9, respectively).

In terms of family arrangements, we found similarities with previous studies: i.e. living with a partner increases the chances of being out of the labour market, with a stronger effect for males. However, the contrary effect is found if the occupation status of the partner is taken into account. If the partner is in employment, the probability of an employment exit is reduced; this supports the observation 
Table 4:

Family arrangements' impact on the likelihood of exit from employment. Spanish individuals aged 50-64, period 1999-2012

\begin{tabular}{|c|c|c|c|c|c|c|}
\hline \multirow{2}{*}{$\begin{array}{l}\text { Logistic regression with } \\
\text { random effects }\end{array}$} & \multicolumn{3}{|c|}{ Females } & \multicolumn{3}{|c|}{ Males } \\
\hline & Coeff. & $\mathbf{P}$ & Std. Err. & Coeff. & $\mathbf{P}$ & Std. Err. \\
\hline \multicolumn{7}{|l|}{$\begin{array}{l}\text { Household arrangements } \\
\quad \text { (ref. Living alone) }\end{array}$} \\
\hline with a partner only & 0.123 & $* * *$ & 0.036 & 1.247 & $* * *$ & 0.045 \\
\hline $\begin{array}{l}\text { with a partner and dependent } \\
\text { children }\end{array}$ & -0.098 & $*$ & 0.052 & 0.103 & $* *$ & 0.047 \\
\hline with a partner and parents & -0.327 & $* * *$ & 0.068 & -0.235 & $* *$ & 0.114 \\
\hline $\begin{array}{l}\text { with dependents (children } \\
\text { /parents) }\end{array}$ & -0.539 & $* * *$ & 0.186 & -0.060 & & 0.232 \\
\hline \multicolumn{7}{|l|}{$\begin{array}{l}\text { Partner's employment (ref. not } \\
\text { working) }\end{array}$} \\
\hline Partner is working & -1.388 & $* * *$ & 0.031 & -1.567 & $* * *$ & 0.034 \\
\hline \multicolumn{7}{|l|}{ Control variables } \\
\hline \multicolumn{7}{|l|}{ Age (ref. 50-54) } \\
\hline $55-59$ & 1.213 & $* * *$ & 0.035 & 1.922 & $* * *$ & 0.040 \\
\hline $60-64$ & 2.836 & $* * *$ & 0.050 & 9.950 & $* * *$ & 0.081 \\
\hline \multicolumn{7}{|l|}{ Education (ref. Illiterate) } \\
\hline No schooling & -0.740 & $* * *$ & 0.119 & -2.082 & $* * *$ & 0.169 \\
\hline Primary & -1.171 & $* * *$ & 0.118 & -3.333 & $* * *$ & 0.171 \\
\hline Vocational training & -2.117 & $* * *$ & 0.120 & -3.901 & $* * *$ & 0.174 \\
\hline Secondary & -4.628 & $* * *$ & 0.125 & -4.663 & $* * *$ & 0.178 \\
\hline Bachelor's or higher & -14.039 & $* * *$ & 0.136 & -6.892 & $* * *$ & 0.192 \\
\hline \multicolumn{7}{|l|}{ Year (ref. 1999) } \\
\hline 2000 & 0.115 & $* *$ & 0.056 & 0.147 & $* * *$ & 0.052 \\
\hline 2001 & -0.116 & * & 0.065 & 0.165 & $* * *$ & 0.063 \\
\hline 2002 & -0.213 & $* * *$ & 0.068 & 0.182 & $* * *$ & 0.069 \\
\hline 2003 & -0.477 & $* * *$ & 0.069 & 0.102 & & 0.071 \\
\hline 2004 & -1.005 & $* * *$ & 0.068 & 0.091 & & 0.072 \\
\hline 2005 & -1.606 & $* * *$ & 0.069 & 0.218 & $* * *$ & 0.072 \\
\hline 2006 & -2.167 & $* * *$ & 0.069 & 0.065 & & 0.071 \\
\hline 2007 & -2.492 & $* * *$ & 0.069 & -0.029 & & 0.071 \\
\hline 2008 & -2.678 & $* * *$ & 0.070 & 0.285 & $* * *$ & 0.071 \\
\hline 2009 & -2.879 & $* * *$ & 0.070 & 1.099 & $* * *$ & 0.070 \\
\hline 2010 & -3.057 & $* * *$ & 0.071 & 1.475 & $* * *$ & 0.070 \\
\hline 2011 & -3.292 & $* * *$ & 0.071 & 1.828 & $* * *$ & 0.071 \\
\hline 2012 & -3.234 & $* * *$ & 0.074 & 2.644 & $* * *$ & 0.073 \\
\hline Constant & 10.462 & $* * *$ & 0.131 & -4.658 & $* * *$ & 0.179 \\
\hline sigma_u & 8.558 & & 0.029 & 9.945 & & 0.043 \\
\hline Rho & 0.957 & & 0.000 & 0.968 & & 0.000 \\
\hline $\begin{array}{l}\text { No. of observations } \\
\text { (individual-wave) }\end{array}$ & 703,948 & & & 728,499 & & \\
\hline No. of groups (individuals) & 259,766 & & & 182,366 & & \\
\hline
\end{tabular}

$* * * p<0.01, * * p<0.05, * p<0.1$.

Note: Separate models for males and females, controlling for random effects within individuals.

Source: Spanish Labour Force Survey (LFS). 
mentioned in the literature review that retirement timing is often decided jointly within a couple.

In general, we found that having a potentially dependent person living in the household (a child under age 16 or an elderly parent) is negatively associated with the probability of being retired. This finding is contrary to our expectations, especially for females. In the case of women, the family composition in the household does not appear to have negatively conditioned their employment participation. One reason for this result could be that the presence in the household of a parent did not impose a burden; on the contrary, an adult who was living with a parent was more likely to be employed than an adult who was living alone or only with a partner. To further analyse this phenomena, other variables should be taken into account, such as the health of the parent, or the individual's reasons for being out of the labour market.

We were, however, surprised to find that men had a greater likelihood of exiting the labour market if they were living with a partner and children (under age 16); although the likelihood of an exit was much lower than it was if they were living with a partner only, which could be explained by the joint decision-making of the couple. Moreover, the risk of retirement was lower among men who were living with a partner and dependents (living with children and parents was negatively related, but this result was not statistically significant). In this case, it appears that the need for an income source reduced the likelihood that men would leave employment, especially when other household members could take care of the other needs in the household.

The effect of age was as expected: as the individual approached the age of 65 , the probability of being out of employment increased, with stronger effects for males. The estimates for education were similar: i.e. the higher the level of education an individual had, the lower the probability was that he or she would exit the labour market; although the coefficients differed by sex.

The protective effect of education for employment was higher among males, and the effect was higher until the secondary level, at which point men and women had similar coefficients. For the upper level of bachelor's degree or higher, females had a much higher coefficient; thus, being highly educated had an especially strong effect on the probability of exiting employment among women.

The estimates for the dummy variable of time also showed important differences between males and females: for the entire period of analysis (1999-2012), women had increasingly negative coefficients, indicating that their retirement risk declined over time (even after 2008); whereas the variable had the opposite effect among men. Men had positive signs for all of the years (except for 2007, although this was not statistically significant), which implies that they had a higher risk of retirement than the reference group of 1999. The coefficients indicate that the trends were stable in the early years, and that there were no differences between 2003 and 2007. However, in 2008 the coefficients increased systematically, and the risk of being out of employment rose sharply. 


\section{Discussion}

(Early) retirement patterns have been studied extensively from economic and demographic perspectives, and a wide variety of methods have been applied in these investigations. The purpose of this paper was to investigate the effect of family composition on early retirement for the population near the state pension age of 65 . The Spanish Labour Force Survey (LFS) is a national representative survey which is most often used to study labour market changes. But because these survey data are complex and have only recently become available, they have so far been used mainly in a cross-sectional format, rather than as panel data.

Using the LFS in our study as a panel dataset, we were able to apply a random effects framework to investigate the employment status of the adult Spanish population, thereby taking unobserved heterogeneity and variations within individuals into account.

The first objective of this paper was to analyse the labour market participation of adults between the ages of 50 and 64 . Our findings indicate that men had higher levels of employment than women during the entire period. The results further show that male labour participation followed macro-economic variations, decreasing during times of economic depression and increasing in periods of economic expansion. It is worrying that even during the phases of economic growth in our study period male employment rates did not approach the levels of the 1970s, and that in the first four years of the current crisis the rates had fallen to the lowest levels since the 1970s.

The reverse trend was found for women. Female employment rates grew steadily, and do not appear to have been affected by economic cycles or labour market policies which promoted a reduction in the workforce. Until the late 1980s, less than one-third of women over the age of 50 were participating in the labour market. But the figures since the 1990s suggest that women are becoming increasingly active in the economy. Particularly interesting are the patterns of employment after 2008, which show that labour market participation rates are declining among men but increasing among women.

Our second research objective was to analyse the socio-demographic determinants of the transition to permanent labour inactivity of the adult population in Spain. The results show that the exit from employment is strongly influenced by family arrangements, by education, and-in the case of males-by the economic crisis of 2008.

In terms of family arrangements, living with a partner has been shown to be an important determinant of employment during the early $21^{\text {st }}$ century for both sexes: i.e. in line with the retirement joint decision model, the analysis showed that the chances of an individual being in employment were affected by whether his or her partner was working. This finding is similar to those of several previous studies (Mark et al. 1999; Ortiz 2004; Garrido and Chuliá 2005). Moreover, using separate models for each sex, we found that females were less likely to leave employment for any type of family arrangement except living with a partner only, while males 
who were living with a partner only, or with a partner and dependent children, had an increased risk of entering retirement. However, the presence of an elderly parent (regardless of the presence of others) increased the likelihood of staying in employment. Thus, living with a parent appears to encourage adults to continue working.

Our analyses were adjusted for several covariates to control for the effects of other important predictors. Level of education was found to be a significant determinant of the likelihood or remaining in employment among older adults. Our study population included large shares of individuals who had only a primary school education or vocational training. The results clearly showed that highly educated males and females were more likely to remain in employment after age 50. After controlling for the period of analysis and family composition, this effect was found to be especially strong among women, but comparatively weak among men.

\section{Limitations}

Several limitations of our research should be mentioned here. The analyses conducted for this paper were based on employment status, and considered all of the individuals who reported in the survey that they were not working to be early retirees. Moreover, unmeasured biases could have affected our results. For example, because health status was not recorded in the LFS, we could not control for the health status of the respondents or of their family members. Both health indicators are important predictors of stopping work, as individuals who are disabled or who have informal care responsibilities are less likely to remain in employment (Lindeboom and Kerkhofs 2009; Schneider et al. 2013). We also did not control for other factors, such as differences in retirement patterns by occupational sectors, the trade-off between income earned prior to retirement and pension benefits (Díaz and Llorente 2005; García-Gómez et al. 2014), and cohort pattern changes (Garrido 2004).

Longitudinal datasets are particularly useful for studying transitions and life course events, but there is a scarcity of such datasets in Spain. We therefore used the panel data of the LFS, which have a number of advantages, as was previously discussed. But since we did not have the full employment histories of the individuals, the analysis here refers to the changes which occurred within a year and a half. This short period may not be sufficient to analyse the effects of the changes which occurred over the adult ages before retirement.

\section{Conclusion}

At the start of the $21^{\text {st }}$ century, the Spanish labour market is still characterised by significant gender divisions. This situation should change for younger generations as they approach the SPA (which has already shifted from 65 to 67 in Spain), as 
today's young people will have spent their childhood and adult life in a different social context. In particular, we can expect more women to become actively engaged in the social, political, and economic spheres.

In general, we have confirmed the importance of family composition for individuals as they reach the age of retirement; finding that having a family tends to encourage people to remain in employment rather than to retire early, except among people who live with a partner only. The effect on employment of living with a parent is stronger among females, while among males the presence of a partner, rather than the presence of dependents, appears to have a greater influence.

The improvements in educational attainment during the second half of the $20^{\text {th }}$ century barely affected the population aged 50 and over. However, we expect that subsequent generations in Spain will reach retirement ages with higher levels of education, and that they will therefore be more likely to delay retirement.

Finally, the analysis showed that early exits from employment among adults have not been declining; on the contrary, they have been increasing, at least among men. During the economic expansion, employment rates increased and the risk of early retirement decreased among women; whereas among men employment rates increased moderately, but the risk of early retirement also rose. After the onset of the economic crisis in 2008, these gender-specific trends in labour market attachment among this age group continued: the risks of early retirement increased among men and decreased among women.

Policy implications can be drawn from these results. For instance, the higher rates of early retirement among males could be forcing the partners of those who retire to also stop working. Early retirement schemes seem to play an important role in driving people out of the labour market. We have confirmed that in recent decades a large proportion of the Spanish population have been inactive, even during the expansion of the Spanish economy in the first decade of the $21^{\text {st }}$ century. The finding that highly educated individuals are less likely to retire early reinforces the need for re-qualification and training programmes for the adult population, as such programmes will prepare them to face the requirements of a constantly changing labour market.

\section{Acknowledgements}

An earlier version of this manuscript was presented at the International Conference Health, Education and Retirement over the Prolonged Life Cycle (HERO), Vienna, Austria, November 27-29, 2013. The research is based upon work from the $\mathrm{PhD}$ dissertation of Madelín Gómez-León. The authors would like to thank the editor and anonymous reviewers' comments and suggestions to improve the paper. We also acknowledge support from the research project 'Dinámica del mercado de trabajo y formación familiar en España durante el cambio de siglo' (CS0201021028/SOCI) as well as from the research project 'Spurs in the extension of working 
life: health, training and living arrangements' (CSO2013-48042-R), supported by the 'Ministerio de Economía y Competitividad' of the Spanish government.

\section{References}

Aaronson, S., B. Fallick, A. Figura, J. Pingle and W. Wascher 2006. The recent decline in the labor force participation rate and its implications for potential labor supply. Brookings Papers on Economic Activity (1): 69-154.

Antolín, P. and S. Scarpetta 1998. Microeconometric Analysis of the Retirement Decision. OECD Economics Department Working Papers, 204.

Antón, J., F. Braña and R. Muñóz 2007. Edad efectiva de jubilación en España: un análisis a partir de la explotación de la Muestra Continua de Vidas Laborales de la Seguridad Social. Jornadas de Usuarios de la Muestra Continua de Vidas Laborales. Madrid, Ministerio de Trabajo y Asuntos Sociales y FEDEA.

Auer, P. and M. Fortuny 2000. Ageing of the Labour Force in OECD Countries: Economic and Social Consequences. I. L. O. Employment Sector: Geneva 2000/2.

Baizán, P., A. Aassve and F. C. Billari 2001. Cohabitation, marriage, first birth: The interrelationship of family formation events in Spain. Working Paper WP 2001-036, Rostock, Max Planck Institute for Demographic Research.

Barwell, R. 2001. Age structure and the UK unemployment rate. Quarterly Bulleting, Spring 2001, 41. London: Bank of England.

Blöndal, S. and S. Scarpetta 1998. The retirement decision in OCDE countries. Working Papers. E. Department, OECD, 202.

Bloom, D. E., D. Canning and G. Fink 2011. Implications of Population Aging for Economic Growth. The WDA-HSG Discussion Paper Series on Demographic Issues, ed. M. Bütler, I. Kickbusch and A. Sousa-Poza, No. 2011/2. WDA Forum.

Burtless, G. and R. Moffitt 1984. The effect of social security benefits on the labor supply of the aged. Retirement and Economic Behavior, ed. H. Aaron and G. Burless. Washington DC: The Brookings Institute.

Cano, D., J. L. Cendejas, C. Ruiz and D. Martín 2000. El mercado de trabajo y su medición en España. Estadística Española Vol. 42 (Núm. 146).

Casey, B. and S. Wood 1994. Great Britain: Firm Policy, State Policy and the Employment and Unemployment of Older Workers. Regulating Employment and Welfare: Company and national policies of labour force participation at the end of working life in industrial countries, ed. F. Naschold and B. Vroom, 363-394. Berlin: De Gruyter.

Chan, S. and A. H. Stevens 2001. Job loss and employment patterns of older workers. Journal of Labor Economics 19(2): 484-521.

Christensen, K., G. Doblhammer, R. Rau and J. Vaupel 2009. Ageing populations: the challenges ahead. The Lancet 374(9696): 1196-1208.

Díaz, M. and M. d. M. Llorente 2005. Población y empleo. El futuro del mercado de trabajo. Papeles de Economía Española. Transformación Demográfica: Raíces y consecuencias 104: 227-238. 
Díez, J. 1999. Envejecimiento y políticas hacia los mayores en la Unión Europea. Las estructuras del Bienestar en Europa, ed. S. Muñóz, J. L. García and L. González, 779793. Madrid: Escuela Libre Editorial/ Fundación ONCE y Civitas.

Diggle, P. J., Heagerty, P., Liang K-Y. and Zeger, S.L. 2002. Analysis of Longitudinal Data. Oxford: Oxford University Press.

Dittrich, D., V. Büsch and F. Micheel 2011. Working beyond retirement age in Germany: The employee's perspective. Older Workers in a Sustainable Society, ed. R. Ennals and R. H. Salomon. Peter Lang.

Dixon, S. 2003. Implications of population ageing for the labour market. Labour Market Trends, 67-76. London: Office for National Statistics.

Erdogan-Ciftci, E., E. Van Doorslaer and A. Lopez Nicolas 2008. Health, financial incentives and retirement in Spain. Tinbergen Institute Discussion Paper No. 08-093: 46.

Esping-Andersen, G. 2004. La política familiar y la nueva demografía. Consecuencias de la evolución demográfica en la economía. ICE. 815.

European Union 2012. EEO Review: Employment Policies to Promote Active Ageing 2012. Luxemburg.

Even, W. and D. MacPherson 1994. Gender differences in pensions. The Journal of Human Resources 29: 555-587.

Flippen, C. and M. Tienda 2000. Pathways to retirement: patterns of labor force participation and labor market exit among the pre-retirement population by race, hispanic origin, and sex. Journal of Gerontology 55.

Flores, M. F. 2008. Envejecimiento demográfico y mercado de trabajo: Análisis de los determinantes de la participación laboral de los trabajadores mayores en España. Revista Universitaria de Ciencias del Trabajo Póliticas de empleo y bienestar social, No. 9. (Universidad de Valladolid).

García-Gómez, P., S. Jiménez-Martín and J. Vall-Castelló 2014. Financial incentives, health and retirement in Spain. NBER Working Paper Series w19913.

García, J. 2003. Estables y precarios. Desregulación laboral y estratificación social en España. Madrid: Centro de Investigaciones Sociologicas.

Garrido, L. 2004. Demografía longitudinal de la ocupación. Información Comercial Española, ICE. Consecuencias de la evolución demográfica en la economía (815).

Garrido, L. and E. Chuliá 2005. Ocupación, formación y el futuro de la jubilación en España. Madrid: Consejo Económico y Social, España.

Gendell, M. 2001. Retirement age declines again in 1990s. Monthly Labor Review Online 124(10).

Gómez-León, M. 2013. Salidas de Ocupación de los Adultos Mayores en España, 1956-2012. Doctoral Thesis, Universitat Autónoma de Barcelona.

Greene, W. 2004. Interpreting estimated parameters and measuring individual heterogeneity in random coefficient models. S. S. o. B. Department of Economics. New York: New York University.

Gruber, J. and D. A. Wise, Eds. 1999. Social security and retirement around the world. International Social Security, University of Chicago Press.

Hofäcker, D. P., S. 2006. Late careers and career exits. An international comparison of trends and institutional background patterns. Globalization, uncertainty and late careers 
in society, ed. H. P. B. Blossfeld, S. Hofacker, and D. Abingdon, 25-53. Routledge.

Lindeboom, M. and M. Kerkhofs 2009. Health and work of the elderly: subjective health measures, reporting errors and endogeneity in the relationship between health and work. Journal of Applied Econometrics 24(6): 1024-1046.

López, L. 2004. Aumentar el empleo de los trabajadores de más edad y retrasar su salida del mercado de trabajo. Revista del Ministerio de Trabajo e Inmigración (\#52): 210.

López, L. 2004. Aumentar el empleo de los trabajadores de más edad y retrasar su salida del mercado de trabajo. Revista del Ministerio de Trabajo e Inmigración. Documentación e Informes (52): 189-210.

Mark, Y. A., B. J. Christensen and N. D. Gupta 1999. A Bivariate Duration Model of the Joint Retirement Decisions of Married Couples. Working Paper. C. f. L. M. a. S. Research. Aarhus: Denmark. 99-10.

Miret-Gamundi, P. and M. Gómez-León 2009. Evolución de las salidas de la actividad laboral en los adultos mayores en España, período 1984-2004. Despoblación, envejecimiento y territorio: un análisis sobre la población española, ed. L. López, A. Abellán and D. Godenau, 431-440. León: Universidad de León.

Nickell, S. 2003. A picture of European unemployment: success and failure. CEP Discussion Paper, 577.

OECD 2013. Effective age of labour market exit. Pensions at a Glance 2013: OECD and G20 Indicators. OECD.

Olmo, F. d. and J. A. Herce 2011. Cambios en el ciclo vital: Retraso de decisiones individuales y contingencias biográficas. Panorama Social Retos de la sociedad española (13).

Ortiz, L. 2004. Leaving the Labour Market: Event-History Analysis of the Male and Female Transitions to Inactivity In Denmark, Germany, Great Britain and Spain. 2nd. ESPAnet Conference, University of Oxford, Department of Political \& Social Sciences.

Oswald, C. 1999. Patterns of labour market exit in Germany and the UK. Working Paper Series, Institute for Social and Economic Research.

Pinzón-Fonseca, D. A. 2011. The Relationship between Health and Employment. Empirical Study for USA. MSc, Erasmus University of Rotterdam.

Puyol, R. 2005. La población española en el marco de la Unión Europea. Papeles de Economía Española. Transformación Demográfica: Raíces y consecuencias 104: 2-16.

Quinn, J. 1999. Has the early retirement trend reversed?, 424. Department of Economics: Boston College.

Ruhm, C. 1996. Gender differences in employment behaviour during late middle life. The Journal of Geronotology 51(B).

Schneider, U., B. Trukeschitz, R. Muhlmann and I. Ponocny 2013. Do I stay or do I go?-job change and labor market exit intentions of employees providing informal care to older adults. Health Econ 22(10): 1230-1249.

Shultz, K. S., K. R. Morton and J. R. Weckerle 1998. The Influence of Push and Pull Factors on Voluntary and Involuntary Early Retirees' Retirement Decision and Adjustment. Journal of Vocational Behavior 53.

Sicherman, N. and O. Galor 1990. A Theory of Career Mobility. Journal of Political Economy 98(1): 169-192. 
Zubiri, I. 2003. El futuro del sistema de pensiones en España. Madrid, Instituto de Estudios Fiscales.

\section{Appendix}

Table A.1:

Classification of education levels used in the Labour Force Survey, Spain

\begin{tabular}{|c|c|c|c|}
\hline Educational level & $\begin{array}{c}1992 \\
\text { I/1992-IV/1999 }\end{array}$ & $\begin{array}{c}2000 \\
\text { I/2000-IV/2004 }\end{array}$ & $\begin{array}{c}2000 \\
\text { I/2005- }\end{array}$ \\
\hline Illiterate or non-schooled & $0,1,2$ & $0-3$ & $80,11,12$ \\
\hline Primary & 3 & 04,05 & $21-23$ \\
\hline Vocational training & 5,6 & $06,07,9-13$ & $31,33,34,36,41,51,53$ \\
\hline Secondary & 4 & 08 & 32 \\
\hline Bachelor's or higher & $7,8,9$ & $15-19,20-31$ & $(50), 52,54-56,(59), 61$ \\
\hline
\end{tabular}

Note: Roman numbers correspond to the trimester in the year.

Source: Methodological documentation from the Spanish Labour Force Survey (LFS), www.ine.es. 
Table A.2:

Coefficients from the random effect and logistic regression models of exit from employment. Spanish individuals aged 50-64, period 1999-2012

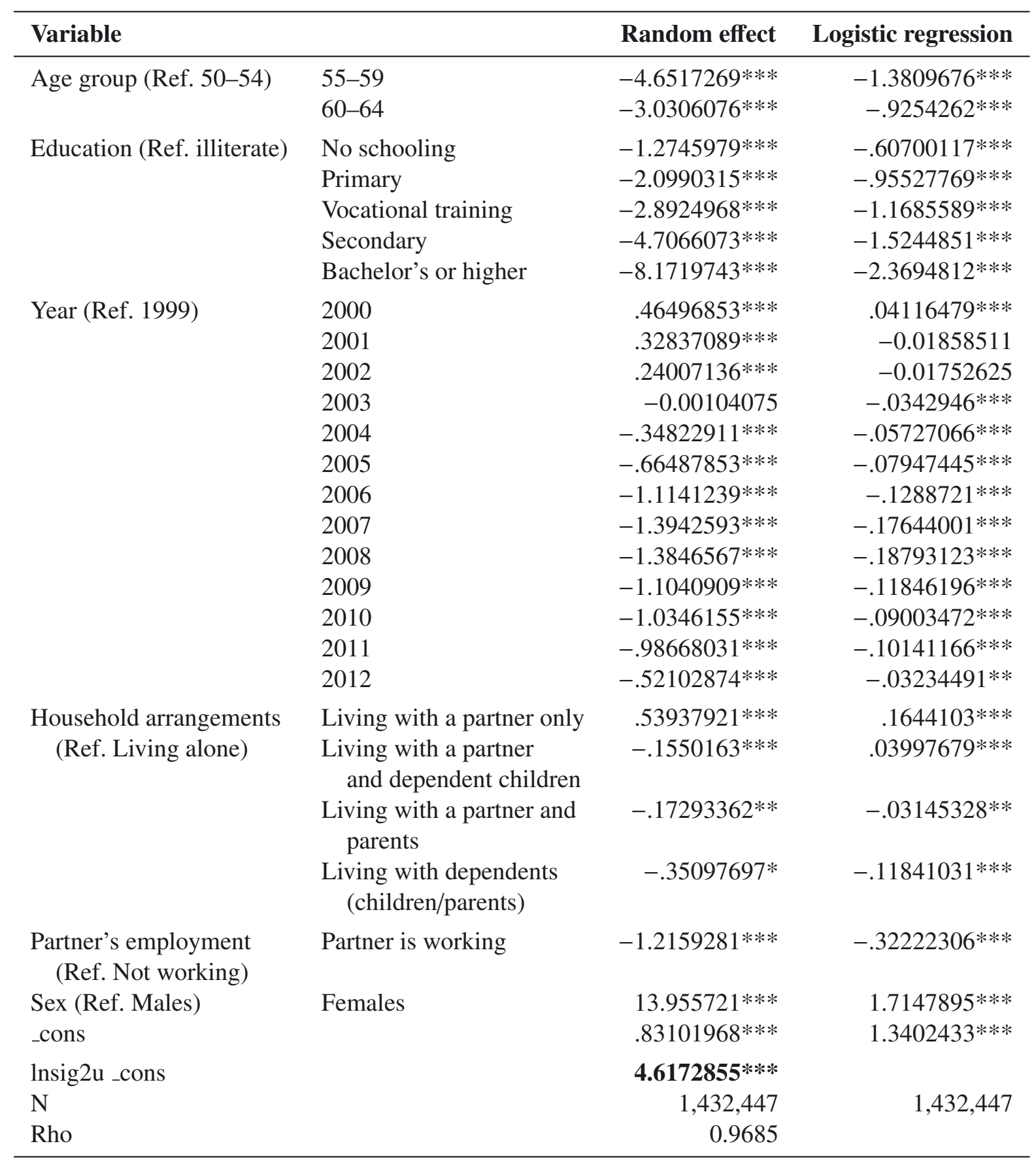

Note: Legend: * $p<0.05$; ** $p<0.01$; *** $p<0.000$.

Source: Spanish Labour Force Survey (LFS). 